\title{
TOXICITY OF INSECTICIDES USED IN MELON CROPS TO Opius scabriventris (Hymenoptera: Braconidae)
}

\author{
TOXICIDADE DE INSETICIDAS UTILIZADOS NA CULTURA DO MELOEIRO \\ PARA Opius scabriventris (Hymenoptera: Braconidae)
}

\section{Elton Lucio ARAUJO' ${ }^{1}$; Carlos Henrique Feitosa NOGUEIRA ${ }^{2}$; Carlos Eduardo Souza BEZERRA ${ }^{3}$; Ewerton Marinho COSTA ${ }^{4}$}

1. Professor, Doutor, Universidade Federal Rural do Semi-Árido, Mossoró, RN, Brasil; 2. Doutorando em Entomologia Agrícola, Universidade Federal Rural de Pernambuco, Recife, PE, Brasil; 3. Pós doutorando em Entomologia, Universidade Federal de Lavras, Lavras, MG, Brasil; 4. Doutorando em Fitotecnia, Universidade Federal Rural do Semi-Árido, Mossoró, RN, Brasil. ewertonmarinho10@hotmail.com

\begin{abstract}
Melon cultivation is an important agricultural activity in the Northeastern Region of Brazil. During its commercial cultivation, the melon crop is attacked by pests, mainly leafminers Liriomyza sativae Blanchard and Liriomyza trifolii (Burgess) (Diptera: Agromyzidae). To keep leafminer populations below an economic issue level, it is essential to adopt control measures such as spraying insecticides and biological control. However, there is little information on the toxicity of insecticides used in the melon crop against leafminers' natural enemies. Therefore, the aim of this study was to evaluate the toxicity of insecticides used in melon crops against the parasitoid Opius scabriventris, a natural enemy of leafminers from the genus Liriomyza (Diptera: Agromyzidae). The experiment was conducted under controlled laboratory conditions, in a completely randomized design, using two bioassays: I - Contact of parasitoids with a recently sprayed surface; and II - Contact of parasitoids with a surface containing dried residues of the insecticides that were significantly toxic in the bioassay I. In both bioassays, the toxicity of the insecticides was evaluated by observing parasitoid mortality. In bioassay I, from eight insecticides tested, only Cartap hydrochloride and Abamectin + mineral oil were considered harmful (Class 4) and Deltamethrin showed to be slightly harmful (class 2). Only Abamectin + mineral oil was harmful (Class 4) to the parasitoid O. scabriventris in the bioassay II. These are the first results regarding the effect of insecticides used in the management of melon pests on the parasitoid of the leafminer fly O. scabriventris.
\end{abstract}

KEYWORDS: Biological control. Integrated Pest Management. Parasitoid. Agricultural entomology

\section{INTRODUCTION}

Melon cultivation is an important agricultural activity in Brazil, especially in the Northeastern Region, which accounts for over than $80 \%$ of the national production, mostly for the export market, mainly to Europe (IBGE, 2012). Besides income, melon production chain generates about 28,000 direct jobs and 84,000 indirect jobs, contributing to the social development of that region (IBRAF, 2008).

During its cultivation, melon is attacked by pests, mainly by the leafminers Liriomyza sativae Blanchard and Liriomyza trifolii (Burgess) (Diptera: Agromyzidae) (GUIMARÃES et al., 2008; ARAUJO et al., 2013). High leafminer populations are a major problem to melon production in northeastern Brazil because their larvae consume the leaf's photosynthetic area, reducing the sugar content of the fruit ( ${ }^{\circ}$ Brix) (ARAUJO et al., 2007; ARAUJO et al., 2013).

To keep leafminer populations below an economic issue level, it is essential to adopt control measures such as insecticide spraying. However, market demands for fruit crops produced with minimal spraying, without the risk of having residues above legal limits, in addition to environmental concerns, require the integration of control methods, as recommended by integrated pest management (IPM) and integrated fruit production (IFP). The IPM and the IFP prioritize the use of control tactics that preserve and promote the action of natural enemies, especially parasitoids and predators, to control populations of pest insects (GRUTZMACHER et al., 2004; GUIMARÃES et al., 2008).

Thus, the significant presence of natural enemies of leafminers, such as the parasitoid Opius scabriventris Nixon, 1955 (Hymenoptera: Braconidae), in areas cultivated with melon, justifies the inclusion of the biological control into the IPM strategies against melon leafminers in northeastern Brazil (ARAUJO et al., 2008). In different parts of the world, there are reports of effective contributions of parasitoids from the genus Opius in regulating populations of Liriomyza sp., with the commercialization of some species of Opius to control agromyzidae in greenhouses in Europe and the U.S. (WHARTON, 1993; MURPHY; LA SALLE, 1999; PETCHARAT et al., 2002). 
In the search for a better usage of parasitoids into IPM programs, studies on the selectivity of insecticides to these natural enemies have been conducted in several crops (LARA et al., 2002; HERNÁNDEZ et al., 2010; NOGUEIRA et al., 2011). According to Prijono et al. (2004), Hossain and Poehling (2006) and El Bouhssini et al. (2008), insecticides based on Abamectin and Pyrethroids are the most toxic to parasitoids from the genus Opius, while Cyromazine has no toxicity to many species of this group.

However, studies on the toxicity of insecticides to parasitoids from the genus Opius occurring in Brazil are scarce, especially regarding to melon crops. Therefore, considering the relevance of $O$. scabriventris as an important ally against melon leafminers, and the lack of studies on the effect of insecticides on this parasitoid, the objective of this study was to evaluate the toxicity of insecticides used in melon crops against the parasitoid $O$. scabriventris.

\section{MATERIAL AND METHODS}

The work was carried out in an acclimatized room at $25 \pm 1{ }^{\circ} \mathrm{C}, 65 \pm 10 \%$ R.H., and a $12 \mathrm{~h}$ photophase, at the Laboratório de Entomologia Aplicada, Universidade Federal Rural do SemiÁrido (UFERSA), Mossoró, Rio Grande do Norte, Brazil. The tests were conducted using adults of $O$. scabriventris, not separated by sex, aged 24-48 hours, from the maintenance rearing of UFERSA.
Initially, puparia were taken from the laboratory rearing and then placed individually in glass tubes (8.5 $\mathrm{cm}$ height $X 2.5 \mathrm{~cm}$ diameter), with the upper end closed with plastic wrap, where they remained until adult emergence.

The toxicity of the insecticides to the parasitoid was evaluated in two distinct bioassays: I - Contact of parasitoids with a freshly sprayed surface; and II - Contact of parasitoids with a surface containing dried residues of the insecticides. This second bioassay was performed only with the insecticides that showed to be toxic in bioassay I. The exposure of parasitoids to the insecticides was performed inside plastic arenas $(6 \mathrm{~cm}$ height $\mathrm{X} 10$ $\mathrm{cm}$ diameter), with the top covered with an antiaphid netting in order to allow air circulation. During the bioassays, the parasitoids were fed with a honey solution (10\% in distilled water) soaked in filter paper cards $\left(1 \mathrm{~cm}^{2}\right)$.

The treatments consisted of eight insecticides used in melon crops in their maximum doses as recommended by the manufacturers (Table 1). As a control treatment, distilled water was used. The bioassay I consisted of nine treatments, eight insecticides and the control, whereas the bioassay II consisted of four treatments: the three insecticides that were toxic to the parasitoid in bioassay I, plus the control treatment. Each treatment consisted of four replicates, being each replicate characterized by an arena containing five adults of $O$. scabriventris. The experimental design was completely randomized.

Table 1. Insecticides used in the melon crops that were evaluated for the toxicity to the parasitoid Opius scabriventris.

\begin{tabular}{|c|c|c|c|c|}
\hline Active ingredient & Chemical group & Mode of action & Dose (g a.i./L) & Target pest \\
\hline Abamectin* & Avermectin & Contact and ingestion & 0.0180 & Liriomyza spp. \\
\hline Acetamiprid & Neonicotinoid & Systemic & 0.0600 & $\begin{array}{c}\text { Bemisia tabaci } \\
\text { biotype B }\end{array}$ \\
\hline $\begin{array}{c}\text { Cartap } \\
\text { hydrochloride }\end{array}$ & Bis (Thiocarbamate) & Contact and ingestion & 1.2500 & Diaphania spp. \\
\hline Ciromazine & Triazinamine & Systemic and ingestion & 0.9000 & Liriomyza spp. \\
\hline Deltamethrin & Pyrethroid & Contact and ingestion & 0.0075 & Diaphania spp. \\
\hline Thiamethoxam & Neonicotinoid & Systemic & 0.1500 & $\begin{array}{c}\text { Bemisia tabaci } \\
\text { biotype B }\end{array}$ \\
\hline Indoxacarb & Oxadiazine & Contact and ingestion & 0.0360 & Diaphania nitidalis \\
\hline Pyriproxyfen & $\begin{array}{c}\text { Pyridyloxy propyl } \\
\text { ether }\end{array}$ & Contact & 0.1000 & $\begin{array}{l}\text { Bemisia tabaci } \\
\text { biotype B }\end{array}$ \\
\hline
\end{tabular}

* Mineral oil was added (Assist ${ }^{\circledR}$ ) at $0.25 \% \mathrm{v} / \mathrm{v}$ (as recommended by the manufacturer).

In both bioassays, the arenas were sprayed using a manually pressurized sprayer with a flow rate of $0.58 \mathrm{~mL} / \mathrm{s}$ and an average application rate of $0.00583 \mathrm{~mL} / \mathrm{cm}^{2}$, following the recommendations of
Sterk et al. (1999) and as recommended by the IOBC (International Organization for Biological and Integrated Control of Noxious Animals and Plants). For the calculation of the average volume of 
solution sprayed, the method described in Carvalho et al. (2002) was used, according to which 15 filter paper cutouts measuring $13 \mathrm{~cm}^{2}$ each were individually weighed before and after spraying with distilled water. The average was obtained by the difference between the wet weight and the dry weight of the filter paper.

In bioassay I (contact of parasitoids with a freshly sprayed surface), adults of $O$. scabriventris were placed into each arena immediately after the spraying of the treatments (within of the arenas), and then directly exposed to droplets of the insecticides. In bioassay II (contact of parasitoids with a surface containing dried residues of pesticides), the arenas were sprayed with the treatments and then transferred to a ventilated and shady place, where they remained for two hours until all the sprayed products were dried. After this period, the parasitoids were placed inside each arena, being exposed to dry residues of the treatments. In both bioassays, the parasitoids were distributed inside the arenas with the help of an entomological aspirator.

The mortality of parasitoids was evaluated continuously, each hour after the exposure to the treatments, up to 24 hours. Dead insects were those that did not respond to mechanical stimuli at the time of each assessment. These stimuli consisted of touching the insects using a thin paintbrush.

The degree of toxicity of the insecticides against $O$. scabriventris was recorded according to
IOBC indexes (International Organization for Biological and Integrated Control of Noxious Animals and Plants), and the products were classified as follows: Class 1 - harmless $(<30 \%$ mortality), Class 2 - slightly harmful (30-79\% mortality) Class 3 - moderately harmful (80-99\% mortality) and Class 4 - harmful (>99\% mortality).

For data analysis, the values for mortality were subjected to an analysis of variance, and the means were compared using the Scott-Knott test at $5 \%$ probability using $\mathrm{R}$ Software (R DEVELOPMENT CORE TEAM, 2011). No corrections were necessary, since the control treatment recorded no deaths.

\section{RESULTS AND DISCUSSION}

In the bioassay I, Cartap hydrochloride caused mortality of all insects (Figure 1) and was considered harmful (class 4) to O. scabriventris. The toxic effect of this product was observed within the first hour of exposure, when all insects were already dead. It was also found that the contact of insects with the product quickly paralyzed them; they died soon after. According to Lee et al. (2003), these are the main symptoms of poisoning by Cartap hydrochloride, because it competes with acetylcholine for its receptors, inhibiting the mechanisms of conductance of $\mathrm{Na}^{+}$and $\mathrm{K}^{+}$in the postsynaptic membrane, causing insects to remain paralyzed before dying.

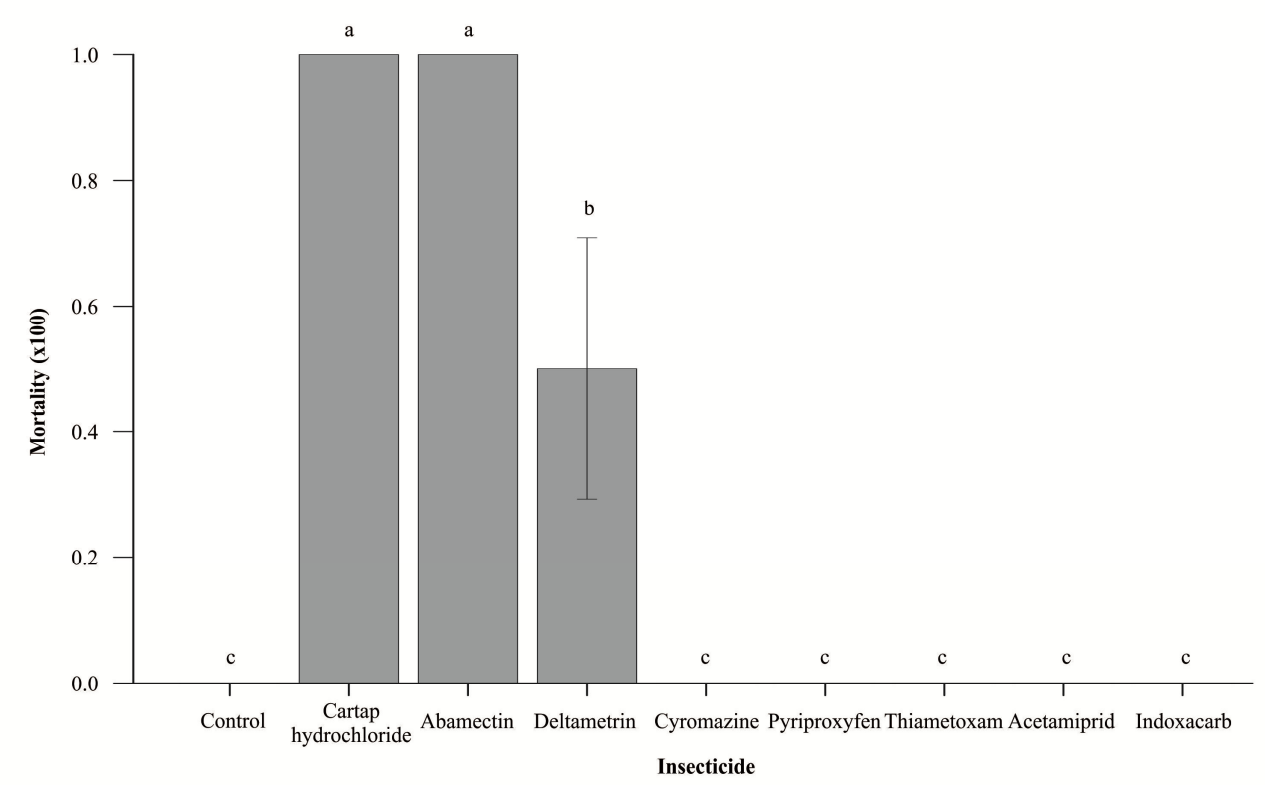

Figure 1. Total mortality of $O$. scabriventris after $24 \mathrm{~h}$ of exposure on a freshly sprayed surface with insecticides used in melon crops. 
Other authors, such as Lara et al. (2002), also reported toxicity of Cartap hydrochloride to Liriomyza sp. parasitoids (Braconidae, Eulophidae and Eucoilidae), and found a $70 \%$ reduction of these natural enemies after spraying this insecticide in fields. It is worth mentioning that several factors can interfere in a field spraying, causing the insects not to be exposed directly to the spray solution, and therefore having a lower mortality.

The treatment Abamectin + mineral oil was also considered harmful (class 4 ) to the parasitoid, causing $100 \%$ mortality at the end of the evaluation period, being statistically equal to Cartap hydrochloride (Figure 1). It was found that $70 \%$ of the insects died within the first six hours of exposure, a slower mortality rate than that caused by Cartap hydrochloride. Bloomquist (1996) notes that Avermectins act by stimulating $\mathrm{Cl}^{-}$flow into the nerve cell, causing a blockage of the transmission of stimuli, so that the insects become paralyzed before death. The noxious effect of Abamectin to parasitoids from the genus Opius was also observed by Prijono et al. (2004), who used half the dose (0.0092 $\mathrm{g}$ a.i./L) used in this study and found a high toxicity of this insecticide to these braconids. Hossain and Poehling (2006) reported that Abamectin is harmful to the parasitoid Opius (Opiothorax) chromatomyiae (Belokobylskij \& Wharton) at a dose of $0.036 \mathrm{~g}$. a.i./L, twice the used in this work.

Deltamethrin caused mortality in $50 \%$ of insects after $24 \mathrm{~h}$ of exposure, differing statistically from the other treatments, and it was considered slightly harmful (class 2) to O. scabriventris. Soon after contact with Deltamethrin, $45 \%$ of the parasitoids quickly showed paralysis followed by death, characterizing a "knock down" effect. This behavior is typical of insects contaminated with pyrethroids because these compounds act preventing the closing of sodium channels, thus blocking the transmission of nerve impulses (WARE; WHITACRE, 2004).

El Bouhssini et al. (2008) evaluated, under field conditions, the effect of Deltamethrin on adults of Opius monilicornis (Fisher), a parasitoid of Liriomyza cicerina (Rondani), at twice the dosage used in this paper, and found that this insecticide was responsible for a $76 \%$ reduction of adults of $O$. monilicornis. Other authors have reported Deltamethrin as moderately harmful to braconids (MANI, 1995; PICANÇO et al., 2003).

Cyromazine, Pyriproxyfen, Thiamethoxan, Acetamiprid and Indoxacarb did not cause mortality of parasitoids and were classified as harmless (Class 1) (Figure 1). The selective effect of Cyromazine can be explained by the fact that this insecticide belongs to the group of triazines, acting mainly in the young stage of the insect, being therefore a potent inhibitor of chitin synthesis in dipteran (FRIEDEL; MCDONEEL, 1985). Also according to these authors, this compound is more effective in early stages and has little or no contact action; it must be ingested by the larvae in order to become active. Our results corroborate the observations of Moreno-Mari et al. (1996) and Prijono et al. (2004), who reported the selectivity of Cyromazine to Opius sp.

The selectivity observed in Pyriproxyfen may be related to its mode of action, once it is an agonist of the Juvenile Hormone ("juvenoid") (MARÇON, 2011). Abdallahi et al. (2000) evaluated two doses of Pyriproxyfen (0.05 - 0.075g a.i./L), lower than that used in this work, on the parasitoid Opius concolor Széplieti, and found that this product did not affect parasitism, but the highest dose used caused a reduction in longevity (53.8\%).

The non-toxicity of Thiamethoxam, Acetamiprid and Indoxacarb to O. scabriventris is probably related to their mode of action. Wing et al. (2000) report that the insecticide Indoxacarb has an activity on insects of the order Lepidoptera, and, according to Nauen and Denholm (2005), neonicotinoids, e.g. Thiamethoxam and Acetamiprid, have a systemic mode of action and are specific for the control of sap feeding (Hemiptera) and defoliator (Coleoptera) insects. Prabhaker et al. (2011) emphasize that neonicotinoids are considered selective to natural enemies, unless they feed on infected plant tissue or on contaminated prey/host.

According to the data obtained in bioassay I, only three insecticides were toxic to $O$. scabriventris: Abamectin + mineral oil, Deltamethrin and Cartap hydrochloride. These three and a control treatment (distilled water) were used in the bioassay II. The parasitoids were exposed to a surface containing dried residues of the products. The treatment with Abamectin + mineral oil caused high mortality on adults of $O$. scabriventris. The first toxic effects of this treatment were observed 20 minutes after exposure, when parasitoids showed the same behavior observed in bioassay I, i.e., after contact with the product, they remained totally paralyzed until death. However, the highest mortality rates occurred after 20 hours. At the end of 24 hours of observation, it was found that this treatment was responsible for $100 \%$ mortality of insects (Figure 2) and was classified as harmful (class 4) at this method of exposure. 


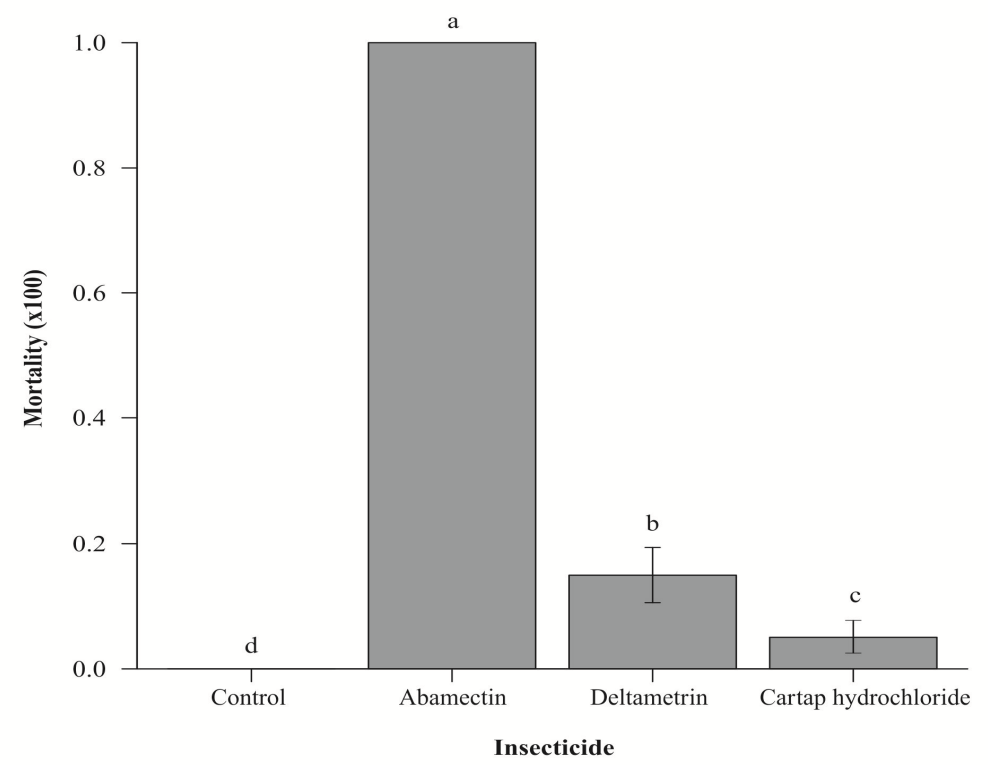

Figure 2. Total mortality of Opius scabriventris after 24 hours of exposure on a surface containing dry residues of insecticides used in melon crops.

The toxic effect of Abamectin may have been prolonged due to its mixing with mineral oil, since, among the products evaluated in bioassay II, this was the single one that kept a high level of toxicity and was the only one mixed with oil. Curran et al. (1999) emphasize that mineral oils can act decreasing the volatility and the photodegradation of insecticides, thus allowing a prolonged effect.

Regarding Deltamethrin, only $15 \%$ of mortality after 24 hours of exposure in this second bioassay (Figure 2) was recorded. Differently from bioassay I, it was classified as harmless (Class 1) to O. scabriventris. In a behavior very similar to that observed for insects contaminated by Cartap hydrochloride, $50 \%$ of the individuals remained totally paralyzed for about 20 hours, starting to move normally after this period.

Differently from the results obtained in bioassay I, Cartap hydrochloride was classified as being harmless to the parasitoid (Class 1) as it caused mortality of only $5 \%$ of parasitoids (Figure 2). It was observed that $40 \%$ of the individuals were completely paralyzed for about 20 hours and then started to move normally. The main symptom of cartap hydrochloride intoxication in insects is paralysis. According to Marçon (2011), this compound inhibits sodium ion conductance in the post-synaptic membrane, blocking neural impulse transmission.

In spite of the insecticides Cartap hydrochloride and Deltamethrin having demonstrated toxic effects to $O$. scabriventris in bioassay I and Abamectin + mineral oil being toxic in both bioassays, a lower field toxicity of these products are expected, since insects' exposure to pesticides under natural conditions is less harmful than in laboratorial experiments. These are the first results on the effect of insecticides to the parasitoid $O$. scabriventris, an important natural enemy of melon leafminers. The information obtained in this study will allow a better-integrated management of Liriomyza in melon crops, increasing the populations of $O$. scabriventris through the adoption of non-toxic insecticides against that parasitoid.

\section{CONCLUSIONS}

Cartap hydrochloride and Abamectin + mineral oil, when sprayed freshly, are harmful to $O$. scabriventris.

Abamectin + mineral oil showed to be toxic even when the parasitoid comes in contact with its dry residues

These two insecticides should be avoided when using an IPM strategy involving the use of this natural enemy, mainly the latter, which remains harmful even if used during the low activity of the parasitoid, for it does not provide an ecological selectivity.

\section{ACKNOWLEDGMENTS}

The authors are grateful to Tiago CostaLima (EMBRAPA) for sending samples of the parasitoid to Dr. Max Fischer (Vienna, Austria) for species' identification. 
RESUMO: O cultivo do meloeiro é uma importante atividade agrícola na região Nordeste do Brasil. Durante seu cultivo comercial, o meloeiro é acometido por pragas, destacando-se as moscas minadoras Liriomyza sativae Blanchard e Liriomyza trifolii (Burgess) (Diptera: Agromyzidae). Para manter a população da mosca minadora abaixo do nível de dano econômico, é essencial a adoção de medidas de controle, como a aplicação de inseticidas e o controle biológico. No entanto, são escassas informações sobre a toxicidade dos inseticidas utilizados na cultura do meloeiro sobre os inimigos naturais da mosca minadora. Portanto, o objetivo deste trabalho foi avaliar a toxicidade de inseticidas utilizados na cultura do meloeiro sobre o parasitoide Opius scabriventris, inimigo natural de moscas minadoras do gênero Liriomyza (Diptera: Agromyzidae). O experimento foi conduzido em condições de laboratório, em delineamento inteiramente casualizado, utilizando dois bioensaios: I - Contato dos parasitoides com superfície recém pulverizada e II Contato dos parasitoides com superfície contendo resíduos secos dos inseticidas que foram tóxicos no bioensaio I. Nos dois bioensaios, a toxicidade dos inseticidas foi avaliada por meio da observação da mortalidade dos parasitoides. No bioensaio I, dentre os oito inseticidas avaliados, somente Cloridrato de Cartap e Abamectina + óleo mineral foram considerados nocivos (classe 4), e Deltametrina mostrou-se levemente nocivo (classe 2). No bioensaio II, apenas Abamectina + óleo mineral foi prejudicial (classe 4) ao parasitoide O. scabriventris. Estes são os primeiros resultados relacionados ao efeito de inseticidas utilizados no manejo de pragas do meloeiro sobre o parasitoide da mosca minadora $O$. scabriventris.

PALAVRAS - CHAVE: Controle biológico. Manejo Integrado de Pragas. Parasitoide. Entomologia agrícola

\section{REFERENCES}

ABDALLAHI, E.; ADÁN, A.; VIÑUELA, E. Toxicity of pyriproxyfen and fipronil on Opius concolor Szèpligeti (Hymenoptera: Braconidae) and Ceratitis capitata (Wiedemann) (Diptera: Tephritidae). Boletín de Sanidad Vegetal Plagas, v. 26, n. 4 p. 503-511, 2000.

ARAUJO, E. L.; FERNANDES, D. R. R.; GEREMIAS, L. D.; MENEZES NETTO, A. C.; FILGUEIRA, M. A. Mosca minadora associada á cultura do meloeiro no semi-árido do Rio Grande do Norte. Revista Caatinga, Mossoró, v. 20, n. 3, p. 210-212, 2007.

ARAUJO, E. L.; FERNANDES, D. R. R.; GEREMIAS, L. D.; FILGUEIRA, M. A.; GUIMARÃES, J. A.; MESQUITA, A. L. M.; SOBRINHO, R. B. Controle biológico de pragas do meloeiro. In: SOBRINHO, R. B.; GUIMARÃES, J. A.; FREITAS, J. A. D.; TERAO, D. (Org.). Produção Integrada de Melão. Fortaleza: Embrapa, 2008, p. 201-206.

ARAUJO, E. L.; NOGUEIRA, C. H. F.; MENEZES NETTO, A. C.; BEZERRA, C. E. S. Biological aspects of the leafminer Liriomyza sativae (Diptera: Agromyzidae) on melon (Cucumis melo L.). Ciência Rural, Santa Maria, v. 43, n. 4, p. 579-582, 2013. http://dx.doi.org/10.1590/S0103-84782013000400003

BLOOMQUIST, J. R. Ion channels as targets for insecticides. Annual Review of Entomology, Palo Alto, v. 41, p. 163-190, 1996. http://dx.doi.org/10.1146/annurev.en.41.010196.001115

CARVALHO, G. A.; CARVALHO, C. F.; SOUZA, B.; ULHÔA, J. L. R. Seletividade de inseticidas a Chrysoperla externa (Hagen) (Neuroptera: Chrysopidae). Neotropical Entomology, Londrina, v. 31, n. 4, p. 615-621, 2002. http://dx.doi.org/10.1590/S1519-566X2002000400015

CURRAN, W. S.; McGLAMERY, M. D.; LIEBL, R. A.; LINGENFELTER, D. D. Adjuvants for enhancing herbicide performance. Agronomy Facts 37. Penn State College of Agricultural Sciences, 1999. p. 1-5. Accessed on july 21, 2013. Online. Available from: http://pubs.cas.psu.edu/freepubs/pdfs/uc106.pdf

EL BOUHSSINI, M.; MARDINI, K.; MALHOTRA, R. S.; JOUBI, A.; KAGKA, N. Effects of planting date, varieties and insecticides on chickpea leaf miner (Liriomyza cicerina R.) infestation and the parasitoid Opius minilicornis F. Crop Protection, v. 27, n. 6, p. 915-919, 2008. http://dx.doi.org/10.1016/j.cropro.2007.11.006 
FRIEDEL, G.; McDONELL, P. A. Cyromazine inhibits reproduction and larval development of the australian sheep blow fly (Diptera: Calliphoridae). Journal of Economic Entomology. Riverside, v. 78, n. 4, p. 868-873, 1985. http://dx.doi.org/10.1093/jee/78.4.868

GRUTZMACHER, A. D.; ZIMMERMANN, O.; YOUSEF, A.; HASSAN, S. A. The side-effects of pesticides used in integrated production of peaches in Brazil on the egg parasitoid Trichogramma cacoeciae Marchal (Hymenoptera, Trichogrammatidae). Journal of Applied Entomology, v. 128, n. 6, p. 377-383, 2004. http://dx.doi.org/10.1111/j.1439-0418.2004.00800.x

GUIMARÃES, J. A. et al. Manejo integrado de pragas do meloeiro. p. 183-199. In: BRAGA SOBRINHO, R.; GUIMARÃES, J. A.; FREITAS, J. A. D.; TERÃ̃O, D. (Eds.) Produção Integrada de Melão. Fortaleza: EMBRAPA Agroindustrial Tropical, 2008. 338p.

HERNÁNDEZ, R.; HARRIS, M.; LIU, T. X. Impact of insecticides on parasitoids of the leafminer, Liriomyza trifolii, in pepper in south Texas. Journal of Insect Science, Madison, v. 11, n. 61, p. 1-14, 2011. http://dx.doi.org/10.1673/031.011.6101

HOSSAIN, M. B.; POEHLING, H. M. Non-target effects of three biorationale insecticides on two endolarval parasitoids of Liriomyza sativae (Dip., Agromyzidae). Journal of Applied Entomology, v. 130, n. 6-7, p. 360367, 2006. http://dx.doi.org/10.1111/j.1439-0418.2006.01072.x

IBGE. Lavoura Temporária. Available from: <http://www.ibge.gov.br/estadosat/>. Accessed 19/11/2012.

IBRAF. Exportações 2007. Available from: < http://www.ibraf.org.br/estatisticas/exportacao.asp >. Accessed: Jan. 02, 2008.

LARA, R. I. R.; PERIOTO, N. W.; SANTOS, J. C. C.; SELEGATTO, A.; LUCIANO, E. S. Avaliação de thiamethoxam 250 WG no controle de Liriomyza huidobrensis (Blanchard, 1926) e de sua seletividade sobre himenópteros parasitóides em cultura de batata (Solanum tuberosum L.). Arquivos do Instituto Biológico, São Paulo, v. 69, n. 3, p. 57-61, 2002.

LEE, S. J.; TOMIZAWA, M.; CASIDA, J. E. Nereistoxin and cartap neurotoxicity attributable to direct block of the insect nicotinic receptor/channel. Journal Agricultural and Food Chemical, Davis, v. 51, n. 9, p. 2646-2652. 2003. http://dx.doi.org/10.1021/jf021149s

MANI, M. Studies on the toxicity of pesticides to Cotesia plutellae (Hymenoptera: Braconidae), a parasitoid of diamondback moth, Plutella xylostella (L.). Journal of Insect Science, Madison, v. 8, n. 1, p. 31-33, 1995.

MARÇON, P. G. Modo de ação de inseticidas e acaricidas. 2011. Available online: http://iracbr.org.br/site/upload/bibliografia/mododeacao.doc. Accessed in: Fev. 10, 2011.

MORENO-MARI, J.; ECHEVARRIA-SANSANO, A.; JIMENEZ-PEYDRO, R. Cyromazine effects on Opius concolor Szèpligeti (Hymenoptera: Braconicdae) applied through laboratory host Ceratitis capitata (Wied.) (Diptera: Tephritidae). Applied Entomology and Zoology, v. 31, n. 4, p. 525-529, 1996.

MURPHY, S. T.; LA SALLE, J. Balancing biological control strategies in the IPM of new world invasive Liriomyza leafminers in field vegetable crops. Biocontrol News and Information, v. 20, n. 3, p. 91-104, 1999.

NAUEN, R.; DENHOLM, I. Resistance of insect pests to neonicotinoid insecticides: Current status and future prospects. Archives of Insect Biochemistry and Physiology, v. 58, n. 4, p. 200-215, 2005.

http://dx.doi.org/10.1002/arch.20043 
NOGUEIRA, C. H. F.; OLIVEIRA, J. J. D.; BEZERRA, C. E. S.; MAIA, A. V. P.; ARAUJO, E. L. Efeito de inseticidas alternativos sobre Opius sp. (Hymenoptera: Braconidae), parasitóide da mosca minadora Liriomyza spp. (Diptera: Agromyzidae). Revista Verde de Agroecologia e Desenvolvimento Sustentável, Mossoró, v. 6, n. 1, p. 126-130, 2011.

PETCHARAT, J.; LING, Z.; WEIQIU, Z.; ZAIFU, X.; QUISONG, W. Larval parasitoids of agromyzid leaf miner genus Liriomyza in the southern Thailand: species and their host plants. Songklanakarin Journal of Science and Technology, v. 24, n. 3, p. 467-472. 2002.

PICANÇO, M. C.; MOURA, M. F.; MIRANDA, M. M. M.; GONTIJO, L. M.; FERNANDES, F. L. Seletividade de inseticidas a Doru luteipes (Scudder, 1876) (Dermaptera: Forficulidae) e Cotesia sp. (Hymenoptera: Braconidae) inimigos naturais de Ascia monuste orseis (Godart, 1818) (Lepidoptera: Pieridae). Ciência Rural, Santa Maria, v. 33, n. 2, p. 183-188, 2003. http://dx.doi.org/10.1590/S010384782003000200001

PRABHAKER, N.; CASTLE, S. J.; NARANJO, S. E.; TOSCANO, N. C.; MORSE, J. G. Compatibility of two systemic neonicotinoids, imidacloprid and thiamethoxam, with various natural enemies of agricultural pests. Journal of Economic Entomology, Riverside, v. 104, n. 3, p. 773-781, 2011. http://dx.doi.org/10.1603/EC10362

PRIJONO, D.; ROBINSON, M.; RAUF, A.; BJORKSTEN, T.; HOFFMANN, A. A. Toxicity of chemicals commonly used in indonesian vegetable crops to Liriomyza huidobrensis populations and the Indonesian parasitoids Hemiptarsenus varicornis, Opius sp. and Cronotoma micromorpha, as well as the Australian parasitoids Hemiptarsenus varicornis and Diglyphus isaea. Journal of Economic Entomology, Riverside, v. 97, n. 4, p. 1991-1997, 2004.

R DEVELOPMENT CORE TEAM. R: A language and environment for statistical computing. R Foundation for Statistical Computing, Vienna, 2011. Available from: < http://www.r-project.org/>. Accessed: Mai. 05, 2011.

STERK, G.; HASSAN, S. A.; BAILLOD, M.; BAKKER, F.; BIGLER, F.; BLÜMEL, S.; BOGENSCHÜTZ, H.; BOLLER, E.; BROMAND, B.; BRUN, J.; CALIS, J. N. M.; COREMANS-PELSENEER, J.; DUSO, C.; GARRIDO, A.; GROVE, A.; HEIMBACH, U.; HOKKANEN, H., JACAS, J.; LEWIS, G.; MORETH, L.; POLGAR, L.; ROVERSTI, L.; SAMSOE-PETERSEN, L.; SAUPHANOR, B.; SCHAUB, L.; STÄUBLI, A.; TUSET, J. J.; VAINIO, A.; VAN DER VEIRE, M.; VIGGIANI, G.; VIÑUELA, E.; VOGT, H. Results of the seventh joint pesticide testing programme carried out by the IOBC/WPRS - Working Group 'Pesticides and Benefical Organisms'. BioControl, Netherlands, v. 44, n. 1, p. 99-177, 1999.

http://dx.doi.org/10.1023/A:1009959009802

WARE, G W.; WHITACRE, D. M. Introducción a los insecticidas. The Pesticide Book, $6^{\text {th }}$ Ed. Meister Media Worldwide, Willoughby, Ohio, 2004.

WHARTON, R. A. Bionomics of the Braconidae. Annual Review of Entomology, Palo Alto, v. 38, p. 121143, 1993. http://dx.doi.org/10.1146/annurev.en.38.010193.001005

WING, K. D.; SACHER, M.; KAGAYA, Y.; TSURUBUCHI, Y.; MULDERIG, L.; CONNAIR, M.; SCHNEE, M. Bioactivation and mode of action of the oxadiazine indoxacarb in insects. Crop Protection, v. 19, n. 8-10, p. 537-545, 2000. http://dx.doi.org/10.1016/S0261-2194(00)00070-3 